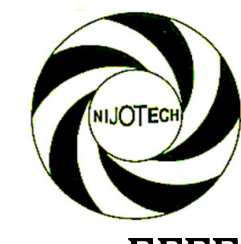

Nigerian Journal of Technology (NIJOTECH)

Vol. 35, No. 1, January 2016, pp. 37 - 42

Copyright@ Faculty of Engineering, University of Nigeria, Nsukka,

Print ISSN: 0331-8443, Electronic ISSN: 2467-8821

www.nijotech.com

http://dx.doi.org/10.4314/njt.v35i1.6

\title{
EFFECTS OF POLYTHENE FIBRES ON SELECTED PROPERTIES OF SANDCRETE BLOCKS
}

\author{
F. B. Ijalana ${ }^{1}$, J. O. Afolayan², O. E. Adeleke ${ }^{3, *}$ \\ 1 Works Department, JoSEPh AYo BABALOLA UnIVERSITY, IKEJI ARAKEJI, OSUN STATE. NIGERIA

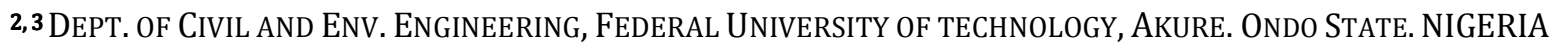 \\ E-mail addresses: ${ }^{1}$ ijanalabode@gmail.com, ${ }^{2}$ joafol@yahoo.com, ${ }^{3}$ oeadeleke88@gmail.com
}

\begin{abstract}
The aim of this study is to explore the possibility of using polythene fibres to increase the strength of sandcrete blocks without increasing the weight and cost of production. It is a comparative study of the properties and performance of polythene reinforced and plain sandcrete blocks. The graded soil sample has a specific gravity of 2.64. Polythene fibres were got from shredded sachet water bags. The fibres were mixed at $0.25 \%, 0.50 \%$ and $0.75 \%$ by mass of the block with sand and cement to produce the reinforced sandcrete at water - cement ratio of 0.4. Compressive strength, water absorption, split tensile strength tests were carried out on the various samples. The results show that the addition of polythene fibre to sandcrete blocks has very little effect on the compressive strength, although at $0.5 \%$ fibre content, the tensile strength increased. Heating the blocks at $100{ }^{\circ} \mathrm{C}$ for 24 hours, the compressive strength of the heated blocks are higher than the non - heated blocks. The results reveal that at an optimum fibre content of $0.5 \%$, fibres are good in reinforcing sandcrete blocks if heated. Addition of polythene fibres to sandcrete blocks will increase the tensile strength and can limit the propagation of cracks.
\end{abstract}

Keywords: Compressive Strength, Polythene Fibre, Sandcrete Blocks, Tensile Strength

\section{INTRODUCTION}

Sandcrete blocks are walling materials that are made of coarse natural sand or crushed rock dust mixed in proportion with cement and water and is compacted to shapes [1]. According to NIS 87 [2] and Barry, 1969 [3], sandcrete block is defined as composite materials made up of cement, sand and water and moulded into different shapes and sizes.

Sandcrete hollow blocks have cavities or large holes passing through them and they are subjected majorly to compressive loads. Seeley [1] grouped sandcrete blocks into two main classes: light weight and dense sandcrete blocks. Light weight blocks are non-load bearing and are not good to be used in substructure but in non-load bearing walls and partitions. Dense blocks are load bearing, and are suitable in substructure and can withstand extreme weather. In civil engineering practice, the strength of sandcrete blocks is assumed to depend on the water-cement ratio and the degree of compaction.

Sandcrete block producers are generally small and operate locally. Researches on improving the quality and as well as producing sandcrete blocks that meet specific user's needs and desires have continued into the millennium. Sandcrete blocks as walling elements in structures; although used for centuries, still represent a challenge to structural analysis due to its complicated, multifaceted mechanical behaviour. It is actually brittle and its quality of construction is difficult to control. Most sandcrete blocks are not designed to support loads other than their own self weight and the weight of the blocks above them when they are used in constructing walls.Compressive strength of blocks is a measure of the blocks resistance to compressive load. The recommended strength by BS 2028, [4] is: mean strength, $3.45 \mathrm{~N} / \mathrm{mm}^{2}$; lowest individual strength, $2.59 \mathrm{~N} / \mathrm{mm}^{2}$. From specification, this implies that the least compressive strength of individual block must be at least $75 \%$ of the mean value. The Federal Ministry of Works and Housing (1979) in Nigeria [5], recommends a compressive mean strength of $2.1 \mathrm{~N} / \mathrm{mm}^{2}$ and lowest individual strength of $1.7 \mathrm{~N} / \mathrm{mm}^{2}$ as recorded by Osuji and Egbon [6]. NIS 87 
[2] specifies that the lowest crushing strength of individual load bearing blocks shall not be less than $2.5 \mathrm{~N} / \mathrm{mm}^{2}$ for machine compacted and $2.0 \mathrm{~N} / \mathrm{mm}^{2}$ for hand compacted blocks. Different studies on the quality of sandcrete blocks produced in Nigeria have shown that the compressive strength of sandcrete blocks do not meet required standards. Aiyewalehinmi and Tanimola [7], Ewa and Ukpata 8], Adeyeye [9] and Mohammed and Anwar 10] among others discovered that the compressive strength of sandcrete blocks produced in their different areas of study fall below the acceptable threshold.

Solid waste disposal has been a major concern in Nigeria. Solid wastes are either degradable (decay) or non-degradable waste. The non-degradable parts of the solid waste are mostly polythene materials. However, according to Maigari [11] in AbdulGaffar [12] as recorded by Dahiru and Usman [13], the world is currently generating billions of tonnes of waste annually but disposes very few millions properly with less than six billion tonnes being re-cycled annually. Sachet water bags constitute a very big chunk in the polythene waste materials. Invariably, the non-bio degradable waste is more of a problem than the biodegradable ones.

The method of disposal of waste in Nigeria is mostly by burning which is not environment friendly as it destroys the ozone layer. There are virtually limited solid waste recycling companies in Nigeria. Despite the fact that these bags have elastic properties yet the re-usability of this material are yet to be fully explored in Nigeria. According to AbdulGaffar [12], the safest, easiest and least expensive ways to reduce material waste production and disposed impact are to produce less, use less, re-use more and re-cycle everything possible of the millions of tonnes of garbage that are produced each year, in the whole world.

Many researches have been carried out to investigate the re-use of waste. Results of investigations showed that many of construction waste can be re-used as renewable material after sorting; removing or crushing e.g., saw dust, scrap iron, scrap wire, demolished concrete waste. Bamboo wood waste can be used in making of man-made timber. Brick, stone, concrete and other waste can replace sand after crushing and used for masonry mortar, plaster mortar, lit the concrete layer, etc. and also used to make brick, road brick, lattice brick and other building materials [10]. Dahiru and Usman [13] assessed the quality of concrete produced with polymer waste as partial replacement of fine aggregate with a view to establishing areas where such concrete can be used Results of the study showed that polymer waste material content has inverse relationship with the workability, compressive and tensile strengths of the concrete. With an increase of $30 \%$ polymer waste material, there was a decrease of about $53 \%$ and $73.3 \%$ decrease in compressive and tensile strengths. Also, Osuji and Egbon [6] carried out an investigation on the optimization of the compressive strength of hollow building blocks using quarry dust and sand. They discovered that 15\% partial replacement of sand with quarry dust have an optimum compressive strength of $3.8 \mathrm{~N} / \mathrm{mm}^{2}$ and $4 \mathrm{~N} / \mathrm{mm}^{2}$ for mix ratio $1: 6$ and 1:8 respectively. In a separate research, Bamidele et al.14] investigated the properties of Pure Water Sachet (PWS) modified Bitumen. The test results show that PWSs influence more on the penetration of the modified sample with the increase in the viscosity of the bitumen as can be observed by the decrease in the value of penetration with the increase in concentration of PWS. The effects of partially replacing sand with saw dust was also studied by Boob [15] where he suggested the use of saw dust as a partial replacement of sand. In a quest to re-use used sachet water bags and improving the properties of sandcrete blocks and not marginally increasing the cost of production, this research investigates the effects of polythene fibres on selected properties of sandcrete blocks.

\section{MATERIALS AND METHODS}

The materials used for the work were sand, shredded used sachet water bags, cement and water. The sand was brought from a borrow pit in Akure. The sand was passed through $3.35 \mathrm{~mm}$ British Standard test sieve and is free from deleterious substances (clay, loam, dirt and any organic or chemical matters). Specific gravity test was carried out on the sand in accordance with BS 1377:2 (1990)[16] with a value of 2.64. Sieve analysis was carried out on the sand used according to BS 812:103[17].

Polythene fibres were obtained from used sachet water bags collected from waste bins located within and outside the University Campus. The water bags were washed, dried and shredded. Chemicals were added to test their effects on the polymers. The size distribution of the polythene fibres was done using statistical method. The brand of cement used is the Elephant Ordinary Portland Cement (OPC), conforming to BS 12 [18] and produced by Lafarge Industries PLC. Potable tap water from a public tap 
within the neighbourhood was used throughout the experiments.

\subsection{Experimental Procedures}

The weight of sandcrete mixture required to produce a block $(450 \times 150 \times 225 \mathrm{~mm})$ from the mould was first determined. The shredded polythene fibres were weighed in percentage in relation to the mass of the block. Manual method of mixing was employed on a clean batching floor (Plate 1). The sandcrete constitutes were mixed manually on a plain surface.The sandcrete constitute were batched by volume with 1 part of cement mixed with 6 parts of sand thoroughly in the dry state until homogeneity was achieved then water was added to form sandcrete. Fifteen blocks without the shredded polythene were first produced using a block molding machine. These are to serve as control units. The shredded polythene was added to the sandcrete by percentage of the mass of the block to produce 15 blocks each for three (3) mix ratios (Cement to Sand) of 1:6, 1:8, 1:10. Also, 12numbers of cylindrical samples $(300 \times 150 \mathrm{~mm}$ diameter.) were taken from each mix for split tensile test and 3 numbers for compressive strength test at 28 days.The specimens were removed from the molds after 24 hours and kept in a curing tank until testing. The specimens were tested at 7, 14, 21 and 28-days in the Concrete Laboratory of the Federal University of Technology, Akure (Plates 2).

\subsection{Compressive Strength Test}

A total number of 48 blocks, three each of same fibre percentage and mix ratio were tested to determine the compressive strength at 7, 14, 21 and 28 days of curing. The sandcrete blocks were carefully placed between the centre of the plates of the compression testing machine with two wooden plates placed above and below the bed surfaces of the block (Plate 3 ).

The crushing/failure loads of the blocks were recorded and the compressive strengths were determined. The strength was calculated by:

$$
\text { Crushing Strenght }=\frac{\text { Maximum Load at Failure }}{\text { Cross Sectional Area of Block }}
$$

\subsection{Splitting Tensile Test}

Standard test cylinders of sandcrete $(300 \mathrm{~mm} \times$ $150 \mathrm{~mm}$ ) were placed horizontally between the loading surfaces of the Compressive Testing Machine. The compression load was applied diametrically and uniformly along the length of the cylinder until failure was observed. Wooden plates were placed between the specimen and loading plates of the testing machine to allow for uniform distribution of the applied load and reduce the magnitude of the high compressive stresses near the points of application of the load.

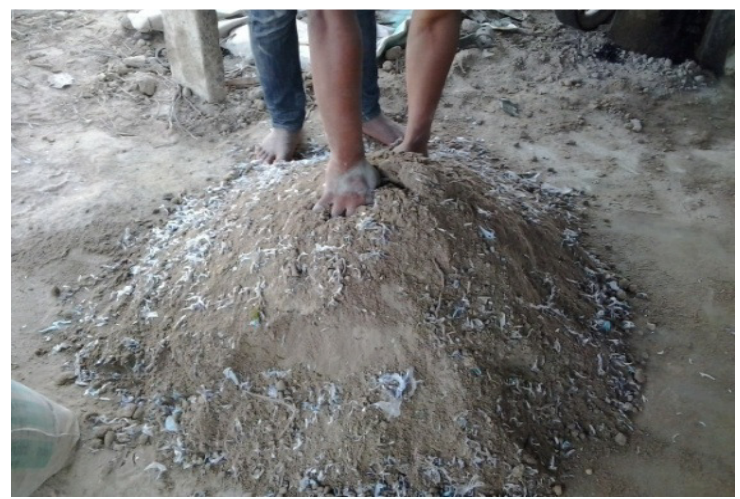

Plate 1: Measured Sand and Shredded Polythene

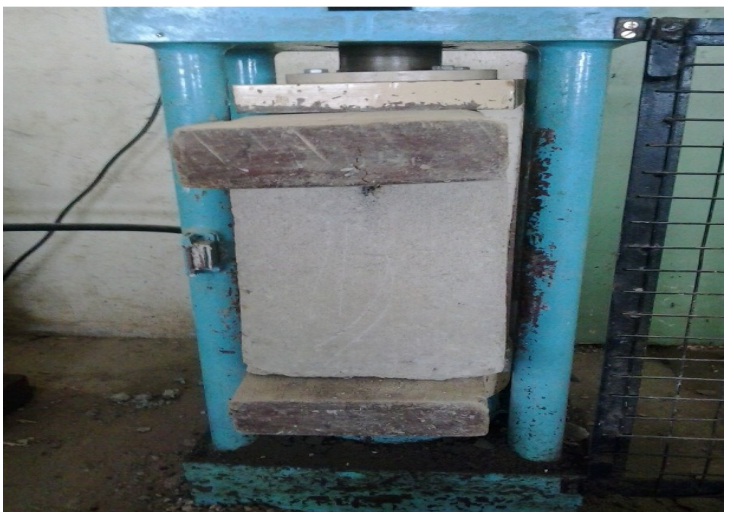

Plate 2: Specimen under Splitting Tensile Load

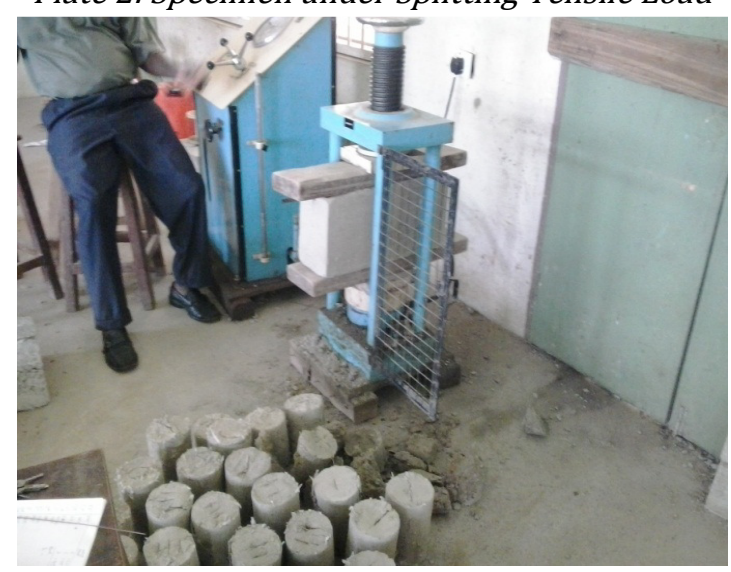

Plate 3: Crushing of Sandcrete Block

The Splitting tensile force $\mathrm{f}_{\mathrm{ct}}$ acting along the vertical plane which caused failure of the specimen was calculated as:

$$
f_{c t}=\frac{2 F}{\pi L D}
$$


In (2), $f_{c t}$ is the tensile splitting strength, in $\mathrm{N} / \mathrm{mm}^{2}, F$ is the maximum load, in $\mathrm{N}, L$ is the length of the specimen, in $\mathrm{mm}, D$ is the diameter of specimen, in $\mathrm{mm}$.

\subsection{Water Absorption Test}

Three Specimens for each fibre content and mix ratio were selected for the test. The samples were weighed in their dry state and were immersed in water for 24 hours. The immersed samples were removed from water; all traces of water were removed from the samples using damp cloth and were weighed. Water absorption, percentage by mass after 24 hours of immersion in water was calculated by

Water Absorption Capacity

$$
=\frac{\text { Wet Weight }- \text { Dry Weight }}{\text { Volume of Block }} \times 100
$$

\subsection{Chemical Test on Polythene Fibres}

The effects of chemicals on shredded sachet water bag were examined. Various chemicals were added to the shredded sachet water bags and visual inspection was employed to see the reactions.

\section{RESULTS AND DISCUSSION}

The properties of materials used for this work were determined. Particle size distribution result is presented in Figure 1 which shows that the sand is well graded. The sand has an average specific gravity of 2.64. The effects of various chemicals on used sachet water bags were examined and presented in Table 1. Of all the five chemicals used, only Acetone shows signs of reducing the size (by shrinking) of the polythene fibres. The results of the compressive strength, split tensile strength and water absorption test of fibre reinforced hollow blocks are presented in Figures2 to 8. From the results, the plain sandcrete blocks have the highest water absorption value (Table 2).The results show that the plain sandcrete has the highest compressive strength. The sandcrete with
$0.75 \%$ fibre has the lowest compressive strength within the limit of this research consideration. The $0.5 \%$ fibre shows a different trend, overlapping with $0.25 \%$ fibre in mix ratio $1: 10$ at 21 and 28days age (Figure 4). There is a jump in strength between 14 and 21 days in mix ratio 1:10. This may be due to moisture entrapment. Polythene fibre blocks did not produce better compressive strength than the plain sandcrete blocks (Figures 2to 4). Increments in the volume of fibre did not produce corresponding increase in the sandcrete compressive strength (Figures 2 to 4 ). There was only a marginal increase in the compressive strength when fibre volume was increased from $0.25 \%$ to $0.5 \%$ in mix ratio $1: 10$ (Figure 4); there was considerable reduction in concrete strength upon increasing the fibre volume to $0.75 \%$ (Figure 4 ). Figure 5 shows that $0.5 \%$ fibre has the greatest splitting tensile strength of $3.35 \mathrm{~N} / \mathrm{mm}^{2}$ for mix ratio1:6. Because of the low resistance of polythene to heat; the effect of heat on the strength of the polythene reinforced blocks was tested and the result is presented in Figure8. The reinforced blocks with $0.5 \%$ fibre has the highest compressive strength as shown in Figure 8 after heating at a temperature of $100^{\circ} \mathrm{C}$ for 24 hours.

Table 1: Effects of chemicals on shredded polythene sachet water bags

\begin{tabular}{|c|c|}
\hline Reagent & Reaction \\
\hline Sample X $+\mathrm{HNO}_{3}$ & $\begin{array}{l}\text { Solvent bleached the nylon and soften it } \\
\text { but does not dissolve it }\end{array}$ \\
\hline $\begin{array}{l}\text { Sample X }+\mathrm{H}_{2} \\
\mathrm{SO}_{4} \\
\text { Sample X + HCL }\end{array}$ & $\begin{array}{l}\text { Solvent burn the sample giving it a } \\
\text { brownish colour but does not dissolve. } \\
\text { No visible reaction }\end{array}$ \\
\hline $\begin{array}{l}\text { Sample X + } \\
\text { Petrol }\end{array}$ & $\begin{array}{l}\text { Solvent soften the sample, there is } \\
\text { probability of bleaching it, giving it a } \\
\text { brownish colour on prolong exposure but } \\
\text { does not dissolve sample. }\end{array}$ \\
\hline $\begin{array}{l}\text { Sample X + } \\
\text { Acetone }\end{array}$ & $\begin{array}{l}\text { Shows possibility to dissolve by bleaching, } \\
\text { softening and reducing size of bits. }\end{array}$ \\
\hline
\end{tabular}

Table 2: Water Absorption Test Results for Sandcrete blocks

\begin{tabular}{|c|c|c|c|c|c|c|c|c|c|c|c|c|}
\hline \multicolumn{13}{|c|}{ Mix Ratio } \\
\hline \multirow[b]{2}{*}{ Fibre \% } & \multicolumn{4}{|c|}{$1: 6$} & \multicolumn{4}{|c|}{$1: 8$} & \multicolumn{4}{|c|}{$1: 10$} \\
\hline & $\begin{array}{l}\text { Dry } \\
\text { (kg) }\end{array}$ & $\begin{array}{l}\text { Wet } \\
(\mathrm{kg})\end{array}$ & $\begin{array}{c}\text { Moisture } \\
\text { Content }\end{array}$ & $\begin{array}{c}\% \\
\text { water } \\
\text { content }\end{array}$ & $\begin{array}{l}\text { Dry } \\
(\mathrm{kg})\end{array}$ & $\begin{array}{l}\text { Wet } \\
(\mathrm{kg})\end{array}$ & $\begin{array}{c}\text { Moisture } \\
\text { Content }\end{array}$ & $\begin{array}{c}\% \\
\text { water } \\
\text { content }\end{array}$ & $\begin{array}{l}\text { Dry } \\
(\mathrm{kg})\end{array}$ & $\begin{array}{l}\text { Wet } \\
(\mathrm{kg})\end{array}$ & $\begin{array}{c}\text { Moisture } \\
\text { Content }\end{array}$ & $\begin{array}{c}\% \\
\text { water } \\
\text { content }\end{array}$ \\
\hline 0 & 20.3 & 22.1 & 1.8 & 8.14 & 20.1 & 22 & 1.9 & 8.64 & 20 & 22.1 & 2.1 & 9.5 \\
\hline 0.25 & 20 & 21.8 & 1.8 & 8.26 & 20.2 & 21.8 & 1.6 & 7.34 & 21 & 22.2 & 1.2 & 5.41 \\
\hline 0.5 & 20.1 & 21.5 & 1.4 & 6.51 & 20.1 & 21.5 & 1.4 & 6.51 & 20.1 & 21.4 & 1.3 & 6.07 \\
\hline 0.75 & 20 & 21.4 & 1.4 & 6.54 & 21.6 & 21.6 & 1.6 & 7.41 & 29.8 & 21.6 & 1.8 & 8.33 \\
\hline
\end{tabular}




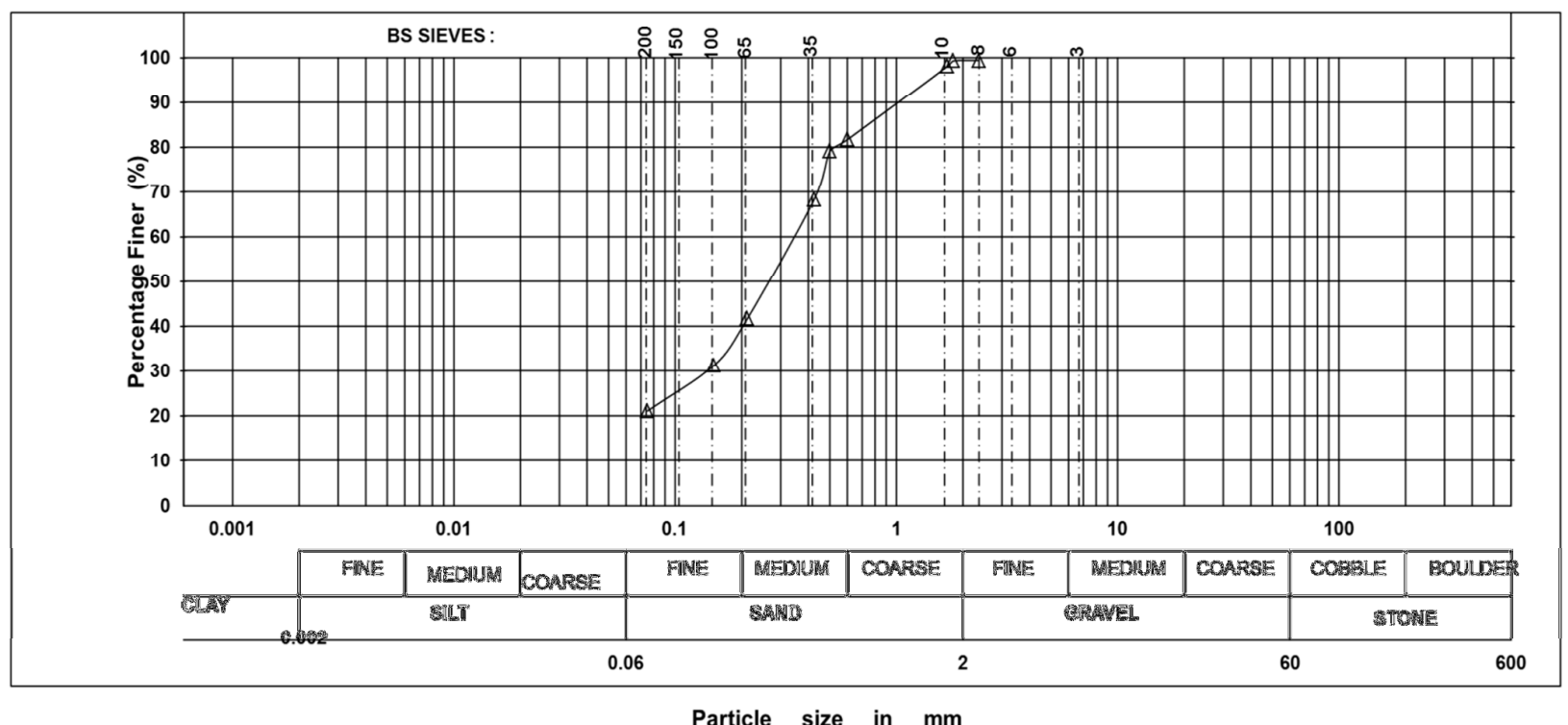

Figure 1: Particle Size Distribution Curve for soil sample.

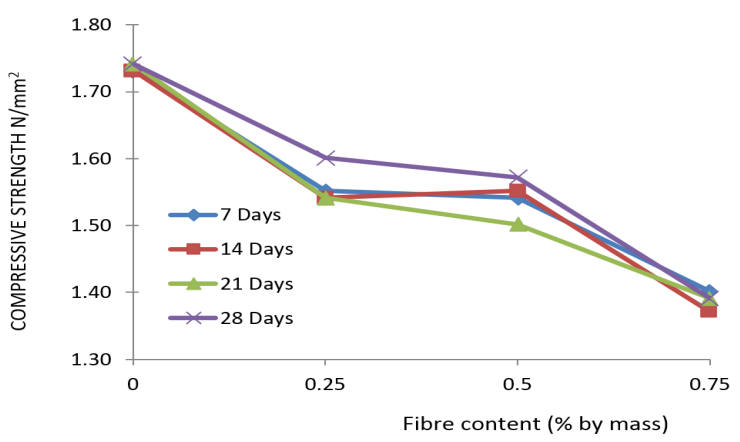

Figure 2: Compressive Strength of Sandcrete Blocks (Mix 1:6)

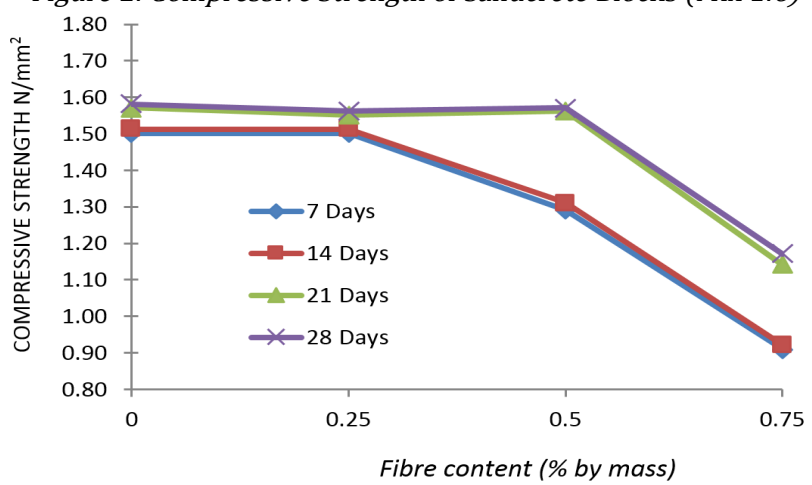

Figure 4: Compressive Strength of Sandcrete Blocks (Mix 1:10)

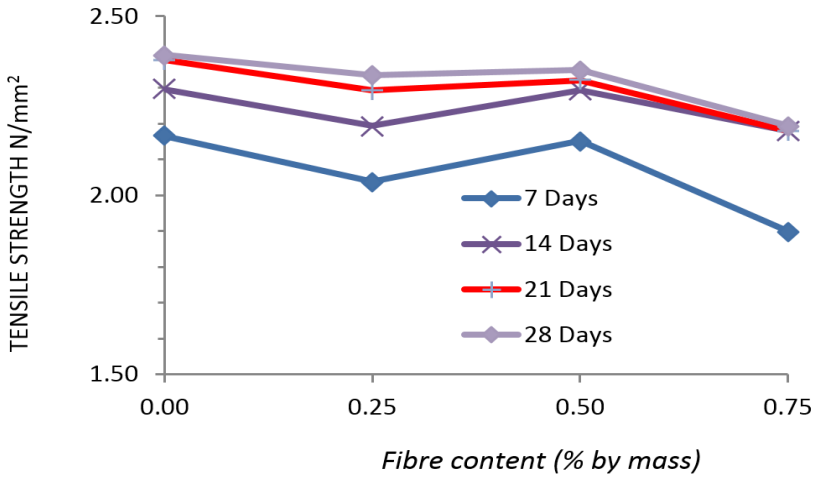

Figure 6: Tensile Strength of Sandcrete Cylinder (Mix 1:8)

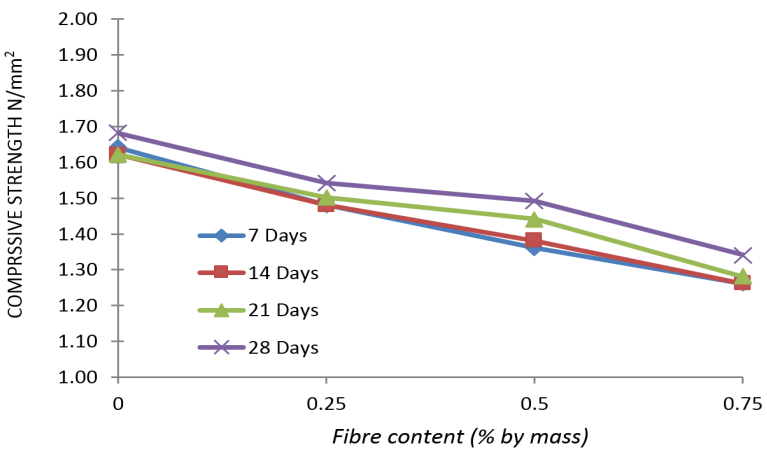

Figure 3: Compressive Strength of Sandcrete Blocks (Mix 1:8)

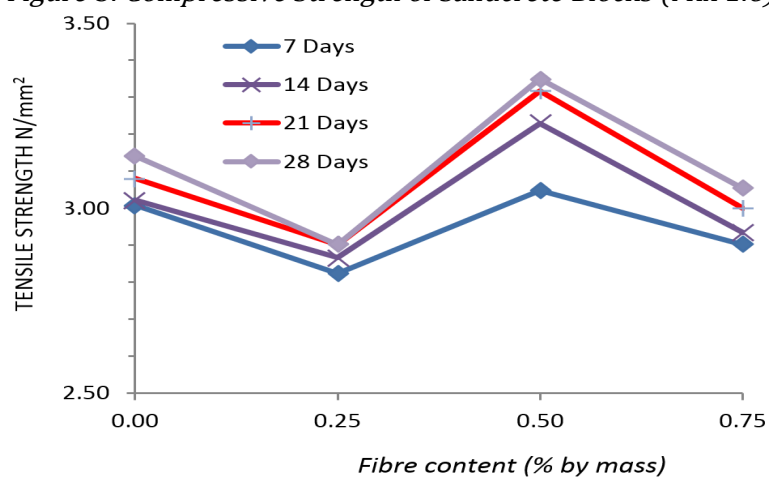

Figure 5: Tensile Strength of Sandcrete Cylinder (Mix 1:6)

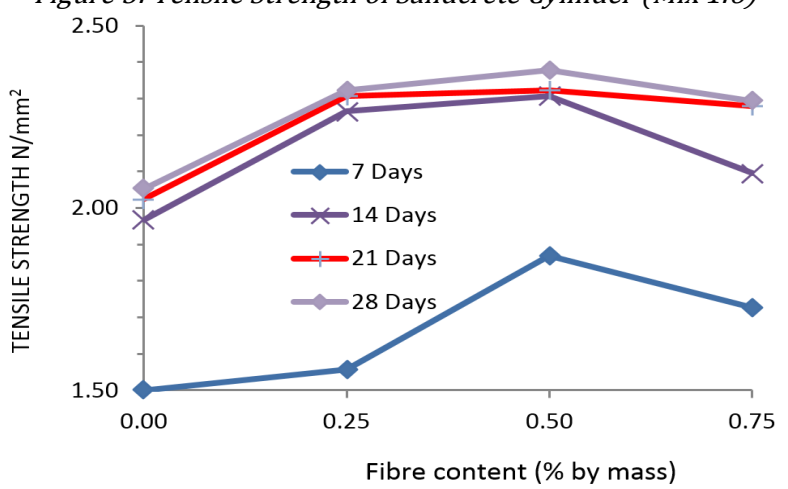

Figure 7: Tensile Strength of Sandcrete Cylinder (Mix 1:10) 


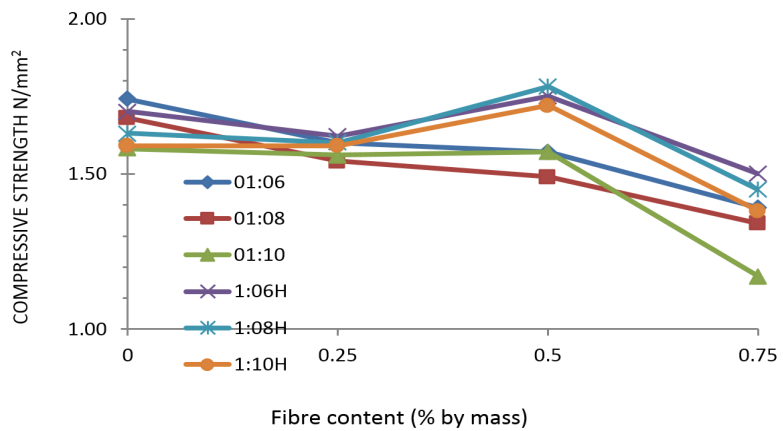

Figure 8: Comparison of Compressive Strength of Heated and Non-heated Sandcrete Blocks

\section{CONCLUSION AND RECOMMENDATION}

In summary the following conclusions were drawn from the tests carried out on polythene fibre reinforced sandcrete blocks with different percentages of polythene fibres and mix ratios.

i. Increase in polythene fibre content in sandcrete blocks lower the compressive strength and has little or no effect in the sandcrete self-weight.

ii. The change in self-weight is marginally low. It can be concluded that there is no increase in self-weight of sandcrete blocks with increase in fibre content.

iii. The water absorption of un-reinforced sandcrete blocks is higher than polythene reinforced sandcrete blocks in mix ratios 1:8 and 1:10. Sandcrete blocks with $0.5 \%$ fibres content show a constant water absorption value in the entire mix ratios. However, it was observed that the higher the fibre content in the sandcrete blocks, the more compact the sandcrete block is after crushing.

iv. The fibre content of $0.5 \%$ shows the highest gain in strength for the three mix ratios.

v. The $0.5 \%$ fibre content shows a high split tensile strength for mix ratio $1: 6$ and 1:10.The Brazilian split tensile test is an indirect tensile strength test, which can be influenced by compressive strength.

This research has shown that the addition of the fibres has helped in limiting the propagation of cracks in sandcrete blocks thereby causing a delay in the ultimate failure of the sandcrete product.

\section{REFERENCES}

[1] Seeley, I. H. (1993) "Building Technology" Macmilan London. $4^{\text {th }}$ Edition. Pp 2.

[2] Nigerian Industrial Standard, NIS 87, (2004) "Standard for Sandcrete Blocks in Nigeria, Timmy Press, Federal Ministry of Industries Lagos (draft). 31.

[3] Barry R. (1969) "The Construction of Buildings". Cross by Lock wood, London, England. Vol.Pp54-55\&94
[4] BRITISH STANDARD INSTITUTION. 1968. BS 2028. "Specification for Precast Concrete Blocks ". BSI. Gayland and Sons Ltd. London.

[5] Federal Ministry of Works Part 2 (1979). "Sandcrete Block Specifications"

[6] Osuji S. O. and Egbon B.N. (2015), "Optimizing Compressive Strength of Hollow Blocks from Granite Quarry Dust and Sand" Nigerian Journal of Technology, 34(3) Pp 478-483.

[7] Aiyewalehinmi E. O. and Tanimola M.O., (2013) "Strength Properties of Commercially Produced Sandcrete Block in Akure: Ondo State" International Journal of Engineering Science Invention, 2(5) Pp 2233.

[8] Ewa D. E., and Ukpata J. O., (2013) "Investigation of the Compressive Strengths of Commercial Sandcrete Blocks in Calabar Nigeria" International Journal of Engineering and Technology, 3(4) Pp 477-482.

[9] Adeyeye A. O., (2013) "Strength Properties of Commercially produced Sandcrete Blocks in Ado Ekiti, Akure and Ile-Ife, Nigeria" International Journal of Engineering Science Invention, 2(8) Pp 25-34.

[10] Mohammed M and Anwar A.R., (2014) "Assessment of Structural Strength of Commercial Sandcrete Blocks in Kano State" Nigerian Journal of Technological Development, 11(2) Pp 39-43.

[11] Maigari, D. D., (1999). Problem of Waste in Nigerianeed for Action. Paper Presented to the House Committee on MGD, NA, Abuja-Nigeria.

[12] AbdulGaffar, S., (2009). The use of renewable construction materials in a building in Nigeria. An Unpublished Final Project Report, Department of Building, Ahmadu Bello University, Zaria-Nigeria, Pp: 120.

[13] Dahiru D. and Usman J. (2014)."Polymer Waste Material as Partial Replacement of Fine Aggregate in Concrete Production" Research Journal of Applied Sciences, Engineering and Technology 7(21) Pp 44044409.

[14] Bamidele, I. O., Dahunsi, O.A., Matiu A., and Oladipupo S.O., (2013) "Investigation of the Properties of Pure Water Sachet Modified Bitumen" Journal of Civil and Environmental Research3(2) Pp 47-61.

[15] Boob T. N., (2014) "Performance of Saw Dust in Low Cost Sandcrete Blocks" American Journal of Engineering Research 3(4) Pp 197-206.

[16] BRITISH STANDARD INSTITUTION. 1990. BS 11377:2 "Methods of Test for Soils for Civil Engineering Purposes". London.

[17] BRITISH STANDARD INSTITUTION. 1985. BS 812: "Methods of determination of Particle Size Distribution". London.

[18] BRITISH STANDARD INSTITUTION. 1996. BS 12: "Specification for Portland Cement". London. 